\title{
Asymmetric tremor due to possible valproic acid-aripiprazole interaction in a child with severe intellectual disability
}

\author{
Şiddetli entellektüel yetiyitimi olan bir çocukta olası valproik asit-aripiprazol \\ etkileşimi ile ilişkili asimetrik tremor
}

\author{
Enes Sarıgedik ${ }^{1}$, Neslihan Kara², Çiğdem Yektaş ${ }^{3}$ \\ ${ }_{1}^{1}$ M. D., Department of Child and Adolescent Psychiatry, Duzce Ataturk State Hospital, Duzce, Turkey https://orcid.org/0000-0002-9294-1152 \\ ${ }^{2}$ M.D. Department of Psychiatry, Duzce University, Medical School, Duzce, Turkey \\ https://orcid.org/0000-0002-2901-8007 \\ ${ }^{3}$ Assoc. Prof., Department of Child and Adolescent Psychiatry, Uskudar University, Medical School, Duzce, Turkey \\ https://orcid.org/0000-0002-5951-7253
}

\section{SUMMARY}

Intellectual disability is a common neurodevelopmental disorder. Antipsychotic drugs, mood stabilizers drugs are often used in this group for behavioral problems. Tremor as a symptom can develop due to the use of both valproic acid and aripiprazole which is usually manifested as symmetrical.When valproate and ari-piprazole are administered together, there may be some change in plasma

concentrations of aripiprazole and its metabolite but this change is thought to be related to the displacement in plasma proteins thus effect of both drugs on changes to steady state levels is very small and not clinically significant We report the case of a 15-year-old girl is that asymmetric tremor, which occurs after valproic acid is added to treatment while using aripiprazole, and the disappearance of asymmetric tremor after reducing the dose of aripiprazole.

Key Words: Valproıc acıd, arıpıprazole, interactıon, asymmetric, tremor

\section{ÖZET}

Entellektüel yetiyitimi yaygın görülen bir nörogelişimsel bozukluktur. bu grupta çocuklar meydana gelen davranış problemlerinin tedavisinde antipsikotik ilaçlar, duygu durum dengeleyiciler sıklıkla kullanılmaktadır. Tremor, hem valproik asit hem de aripiprazol kullanımı nedeniyle gelişebilir ve genelikle simetrik olması beklenmektedir. Valproat ve aripiprazol birlikte uygulandığında, aripiprazol ve metabolitinin plazma konsantrasyonlarında bazı değişiklikler olabilir, ancak bu değişikliğin plazma proteinlerindeki yer değiştirmeyle ilişkili olduğu düşünülmektedir, bu nedenle her iki ilacın kararlı durum seviyelerindeki değişiklikler üzerindeki etkisi çok küçüktür ve klinik olarak önemsiz kabul edilmektedir. bu vaka sunumunda aripiprazol kullanırken tedaviye valproik asit eklenmesi sonrası asitmetrik tremor gelişen sonrasında aripiprazolun dozu azaltığında asitmetrik tremoru kesilen 15 yaşındaki kız olgu sunulmuştur.

Anahtar Sözcükler: Valproik asit, aripiprazol, etkileşim, asimetrik, tremor 


\section{INTRODUCTION}

Intellectual disability is a neurodevelopmental disorder common in children under 15 years of age; its estimated prevalence is $1-3 \%$ whereas severe form of it is estimated to be $6 / 1000(1,2)$. Emotional and behavioral disorders are 3-7 times more common in this clinical group compared to typically developed children. Although there are no drugs approved by the U.S. Food and Drug Administration( FDA) for the treatment of behavioral problems in this group; antipsychotic drugs, mood stabilizers, antidepressants and psychostimulant drugs are often used off-label for reduction of aggression, arousal and behavioural disturbance $(3,4)$.

Aripiprazole which is partial D2 and 5-HT1A agonist, and a 5-HT2A antagonist is frequently used for emotional and behavioural problems in children with intellectual disability due to its low metabolic side effect profile which can be a serious problem for treatment adherence in this group (5). Valproic acid (VPA) which is an antiepileptic drug is commonly used in mood disorders for reducing aggression and also has beneficial effects for behavioral and emotional symptoms in patients with autism and intellectual disability $(6,7)$.

Both aripiprazol and VPA may cause tremor as an extra-pyramidal side effect which usually manifests in a symmetrical manner $(8,9)$. Here, we reported asymmetric tremor as a rare side effect, which occurred after the addition of VPA to aripiprazole treatment in an adolescent girl with intellectual disability and also aimed to draw attention to the possible drug interaction of aripiprazole and VPA .

CASE PRESENTATION: 15-year-old female patient with intellectual disability was brought to our clinic by her family with complaints of violent behaviours, maintenance insomnia and sleepiness during the day, hyperactivity and self-harm. Her peri-postnatal history were normal but there were significant delays in gaining motor and language skills (walking was about at two years old and talking was at four years old). Her current language skills are still very limited with a few sentences and she has not acquired age-appropraite self care skills yet. The patient was evaluated at an another center before and has been still using risperidone 4 $\mathrm{mg} /$ day and methylphenidate (MPH) $50 \mathrm{mg} /$ day for about a year. The family applied to our clinic due to the impaired sleep cycle, increased frequency of urinary incontinence and loss of appetite. In her clinical examination, cooperation could not be establish due to intellectual disability. Aggressive and violent behaviours towards her family and also self harm behavior in terms of hitting herself were observed. It was learned that she had been acting this way for a long time, that she had become worse in the last year, and was more aggressive that her parents and teachers had trouble for controlling her. No psychometric tests could be done due to her non-cooperation. As a result of the clinic evaluation, according to the American Psychiatric Association's Diagnostic and Statistical Manual of Mental Disorders (Fifth Edition) the patient was diagnosed with 'severe intellectual disability' with behavioral problems. Laboratory tests of the patient were found between normal ranges. Treatment regime change was planned because of the aforementioned side effects of risperidone and MPH treatment. Risperidone $4 \mathrm{mg} /$ day was reduced and then discontinued in one week, replaced by aripiprazole $5 \mathrm{mg} /$ day, and dosage of aripiprazole was gradually increased to $20 \mathrm{mg} / \mathrm{day}$ and methylphenidate treatment was also discontinued. Two weeks later, the patient's aggressive behaviours and sleep problems were significantly reduced, frequency of urinary incontinence was decreased, and behavioral problems were partially improved. VPA was added and increased to a daily dosage of 1000 $\mathrm{mg}$ due to her aggressive behaviours and new onset inappropriate sexual behaviors (taking off her clothes in public areas). After a week later, patient applied to our clinic again and she started to make eye contact, her speech was understandable and she interacted with her mother verbally during the assessment. In her neurologic examination; unilateral resting tremor in her right upper limb (between her right shoulder and elbow) was observed yet she had no other symptoms indicating the presence of parkinsonism. VPA level was detected as $40 \mathrm{qg} / \mathrm{ml}$ (under the normal blood level; $50-100 \mathrm{qg} / \mathrm{ml}$ ). Aripiprazole dose was reduced from $20 \mathrm{mg} /$ day to $10 \mathrm{mg} /$ day by considering drug-drug interaction and the patient had significant benefit from VPA treatment. A week later, a phone call 
was made with the family and it was learned that the resting tremor had significantly decreased after aripiprazol dose reduction. One week after the phone call, patient was evaluated at our clinic and resting tremor disappeared completely. Her extrapyramidal system examination was normal and blood level of VPA was reported as $30 \mathrm{qm} /$ day. Her symptoms continued to improve during the first and sixth months of aripiprazole and VPA combination and no side effects were observed except for weight gain which was managed with suitable calorie arrangement.

DISCUSSION: Behavioral problems such as aggression and challenging behaviours are common in individuals with intellectual disability and lack of approved drug group to manage these problems may cause difficulties in symptom control(10). The most commonly used pharmacological agents for the treatment of behavioral problems are; risperidone, aripiprazole, lithium, and anticonvulsants respectively(11). In cases with mild intellectual disability, behavioral recommendations are suggested in the first place, but in more severe cases, the need for pharmacotherapy arises due to inability to manage behavioural symptoms(4). For the high sensitivity to drug side effects in children and adolescents with intellectual disabilities, it is recommended to avoid using multiple drugs, and to start with lower doses and go with slow titration $(12,13)$. However, clinicians may be forced to multidrug use if the condition cannot be controlled by a single drug use or if there is an additional disorder (epilepsy etc.) which requires multidrug treatment. In our case, a combination treatment was continued because the behavioral symptoms couldn't be controlled adequately with only aripiprazole treament. VPA and aripipazole, which are considered to have no significant interaction and do not require dose adjustment, were preferred. Aripiprazole is a partial dopamine D2 receptor agonist antipsychotic is extensively metabolized by the liver enzyme systems; CYP 3A4 and CYP 2D6 (14). At therapeutic concentrations, aripipazole and its active metabolite- dehydro-aripiprazolewhich represents about $39 \%$ of aripipazole in plasma, bind more than $99 \%$ to serum proteins, especially to albumin $(15,16)$. VPA is a broad-spectrum inhibitor of the UGT enzymes, epoxide hydrolase, and CYP2C9 enzymes and no data have been shown that VPA is a CYP2D6 inhibitor or an indu- cer of CYP3A4 and / or CYP2D6(17). When VPA and aripiprazole are administered together, there may be some change in plasma concentrations of aripiprazole and its metabolite(18). This change is thought to be related to the displacement in plasma proteins, and it has been emphasized that the effect of both drugs on changes to steady state levels is very small and not clinically significant(19). It is stated that dose adjustment is not necessary if aripiprazole and VPA are used together based on the studies on adult patients (15-19). Information on the concomitant use and possible interactions of aripiprazole and VPA in the child and adolescent group is very limited(20). In our case, asymmetric tremor was occurred with the addition of VPA to the aripiprazole treatment. Tremor due to VPA is generally expected to be symmetrical and it is rare to be in an asymmetrical manner (21). There is only one case report in the literature, a female peripubertal patient who has diagnosed with epilepsy and developed a left upper extremity tremor in the resting state after VPA treatment with a daily dose of $500 \mathrm{mg}$ and disappeared five days after VPA reduction $(21,22)$. Our case was the second one which may support that unilateral and asymmetric tremors are variants of VPA-induced tremor (22). Interestingly, asymmetric tremor which was developed after VPA treatment disappeared after aripiprazole dose reduction in our case. This suggests that there may be a drug-drug interaction between aripiprazole and valproic acid, contrary to the general opinion mentioned above. The case report may explain this problem as differences in drug metabolism and distribution characteristics in children and adolescents, and also high drug sensitivity in children with intellectual disabilities. We want to emphasize the fact that when dealing with the children and adolescents with intellectual disability, it should be kept in mind that this group is more sensitive and multidrug use should be avoided or managed carefully as much as possible. In addition, more studies are needed for understanding the interaction and extrapyramidal side effects about the concomitant use of aripiprazole and VPA on this group of children.

Correspondence address: M. D. Enes Sarıgedik, Department of Child and Adolescent Psychiatry, Duzce University, Medical School, Duzce, Turkey enessarig@outlook.com 


\section{REFERENCES}

1. Leonard $\mathrm{H}$, Wen $\mathrm{X}$. The epidemiology of mental retardation: Challenges and opportunities in the new millennium. Ment Retard Dev Disabil Res Rev [Internet]. 2002 [cited 2019 Dec 25];8:117-34. Available from: http://doi.wiley.com/10.1002/mrdd.10031

2. American Psychiatric Association. DSM-5 Diagnostic Classification. In: Diagnostic and Statistical Manual of Mental Disorders. 2013.

3. Dykens EM. Annotation: Psychopathology in Children with Intellectual Disability. J Child Psychol Psychiatry [Internet]. 2000 May 28 [cited 2019 Dec 25];41(4):407-17. Available from: https://onlinelibrary.wiley.com/doi/abs/10.1111/1469-7610.00626

4. Bramble D. Psychopharmacology in children with intellectual disability. Adv Psychiatr Treat. 2011;17:32-40.

5. Reurts EE, Troost PW, Dinnissen M, Reijnen S, Hoekstra PJ, Popma A. Aripiprazole in youth with intellectual disabilities: A retrospective chart study. J Intellect Disabil. 2020 Mar $17 ; 174462952090517$.

6. Hollander E, Chaplin W, Soorya L, Wasserman S, Novotny S, Rusoff J, et al. Divalproex sodium vs placebo for the treatment of irritability in children and adolescents with autism spectrum disorders. Neuropsychopharmacology. 2010;35:990-8.

7. Hellings JA, Weckbaugh M, Nickel EJ, Cain SE, Zarcone JR, Reese RM, et al. A double-blind, placebo-controlled study of valproate for aggression in youth with pervasive developmental disorders. J Child Adolesc Psychopharmacol. 2005;15:682-92.

8. Ali R, Singh G, Iskandar JW, Kim KY. A case of intention tremor induced by the combination of aripiprazole and lamotrigine. Vol. 14, Primary Care Companion to the Journal of Clinical Psychiatry. 2012.

9. Baizabal-Carvallo JF, Alonso-Juarez M. Valproate-induced rest tremor and parkinsonism. Acta Neurol Belg. 2019;

10. de Leon J, Greenlee B, Barber J, Sabaawi M, Singh NN. Practical guidelines for the use of new generation antipsychotic drugs (except clozapine) in adult individuals with intellectual disabilities. Vol. 30, Research in Developmental Disabilities. 2009. p. 613-69.

11. Levy T, Bloch Y. [Pharmacotherapy for conduct disorder in children and adolescents]. Harefuah [Internet]. $2012 \mathrm{Jul}$ [cited 2019 Dec 25];151(7):421-6, 435, 434. Available from: http://www.ncbi.nlm.nih.gov/pubmed/23002695

12. Jerrell JM, Hwang T-L, Livingston TS. Neurological adverse events associated with antipsychotic treatment in children and adolescents. J Child Neurol [Internet]. 2008 Dec [cited 2019 Dec 26];23(12):1392-9. Available from: http://www.ncbi.nlm.nih.gov/pubmed/18772491

13. Yen CF, Lin JD, Loh CH, Shi L, Hsu SW. Determinants of prescription drug use by adolescents with intellectual disabilities in Taiwan. Res Dev Disabil. 2009;30:1354-66.

14. Greenaway M, Elbe D. Focus on aripiprazole: A review of its use in child and adolescent psychiatry. Vol. 18, Journal of the Canadian Academy of Child and Adolescent Psychiatry. 2009. p. $250-60$.

15. Citrome L, Josiassen R, Bark N, Salazar DE, Mallikaarjun
S. Pharmacokinetics of Aripiprazole and Concomitant Lithium and Valproate. J Clin Pharmacol [Internet]. 2005 Jan [cited 2019 Dec 19];45(1):89-93. Available from: http://doi.wiley.com/10.1177/0091270004269870

16. Waade RB, Christensen H, Rudberg I, Refsum H, Hermann M. Influence of Comedication on Serum Concentrations of Aripiprazole and Dehydroaripiprazole. Ther Drug Monit [Internet]. 2009 Apr [cited 2019 Dec 19];31(2):233-8. Available from: https://insights.ovid.com/crossref?an $=00007691$ 200904000-00012

17. Jeong H-G, Lee M-S, Ko Y-H, Han C, Jung I-K. Combination Treatment With Aripiprazole and Valproic Acid for Acute Mania. Clin Neuropharmacol [Internet]. 2012 [cited 2019 Dec 19];35(3):97-102. Available from: http://content.wkhealth.com/linkback/openurl?sid=WKPTLP:1 andingpage $\&$ an $=00002826-201205000-00001$

18. Marcus R, Khan A, Rollin L, Morris B, Timko K, Carson W, et al. Efficacy of aripiprazole adjunctive to lithium or valproate in the long-term treatment of patients with bipolar I disorder with an inadequate response to lithium or valproate monotherapy: A multicenter, double-blind, randomized study. Bipolar Disord. 2011;13:133-44.

19. Spina E, Pisani F, De Leon J. Clinically significant pharmacokinetic drug interactions of antiepileptic drugs with new antidepressants and new antipsychotics. Vol. 106, Pharmacological Research. Academic Press; 2016. p. 72-86.

20. Jerrell JM, McIntyre RS. Metabolic, digestive, and reproductive adverse events associated with antimanic treatment in children and adolescents: A retrospective cohort study. Prim Care Companion J Clin Psychiatry. 2010;12(4).

21. Alonso-Juarez M, Baizabal-Carvallo JF. Distinguishing features between valproate-induced tremor and essential tremor. Acta Neurol Scand [Internet]. 2018 Aug [cited 2019 Dec 19];138(2):177-81. Available from: http://doi.wiley.com/10.1111/ane.12953

22. Kakisaka Y, Ito S, Ohara T, Hino-Fukuyo N, Uematsu M, Kure S. Asymmetric drug-induced tremor: Rare feature of a common event. Pediatr Neurol. 2013;48:479-80. 